\title{
Adaptive reuse: an innovative approach for generating sustainable values for historic buildings in developing countries
}

DOI 10.2478/otmcj-2018-0002

Received October 28, 2017; accepted March 24, 2018

Abstract: Sustainable development has become a goal for all countries seeking a balance between social, environmental and economic needs. The principal vision of a sustainable built future is about developing creative designs that utilize energy and materials effectively. However, this vision should consider historic buildings that were built centuries ago. Although many of these buildings are standing in a stable state, they are obsolete and their values are not fully utilized. Towards revitalizing and generating sustainable values of these buildings, adaptive reuse is adopted as a process of modifying, adapting and reusing obsolete buildings with their existing structures to extend their life cycle whilst performing a new function. This is currently practiced worldwide, specifically when a building has a unique architectural character and is in a stable condition. The adaptive reuse of a historic building should have minimal impact on the heritage significance of the building and its setting. This paper aims to investigate the effectiveness of adaptive reuse as an innovative approach for generating sustainable values of historic buildings in developing countries. To achieve this aim, a research strategy is designed to accomplish four objectives: first, literature related to sustainable development, sustainable values, adaptive reuse and developing countries is reviewed; second, two case studies are presented and analysed to investigate the role of adaptive reuse towards increasing the sustainable value of heritage buildings; third, a strategy with its action plan is developed for facilitating adaptive reuse of historic buildings in developing countries and finally, research conclusions are outlined

\footnotetext{
*Corresponding author: Ayman Ahmed Ezzat Othman, Architectural Engineering Department, Faculty of Engineering, The British University in Egypt (BUE), El Shorouk City, Cairo Suez Desert Road, Postal No. 11837, P.O. Box 43, Egypt, E-mail: ayman.othman@bue.edu.eg Heba Elsaay, Architectural Engineering Department, Faculty of Engineering, The British University in Egypt (BUE), El Shorouk City, Egypt
}

and recommendations useful to professionals concerned with adaptive reuse of historic buildings are proposed.

Keywords: adaptive reuse, sustainable development, sustainable values, developing countries

\section{Introduction}

Achieving objectives for sustainable development called for a balance between social, environmental and economic needs of the community and available resources. The principal vision of a sustainable built future is about developing creative designs that utilize energy and smart materials efficiently. In reality, this vision should consider historic buildings that were built centuries ago. There is a growing acceptance worldwide that conserving historic buildings provides significant economic, cultural and social benefits (Bullen and Love 2010). Historic buildings should be conserved for future generations as they link communities with their history. Towards revitalizing and generating sustainable values of these buildings, many historic buildings of cultural and historic significance are being adapted and reused rather than being demolished (Ball 1999; DEH 2004; Wilkinson and Reed 2008; Wilkinson et al. 2009; Bullen and Love 2009). Accordingly, the adaptive reuse of historic buildings is considered as an opportunity for generating sustainable social, environmental and economic values. However, due to their characteristics, developing countries encounter a number of challenges that hinder the process of adaptive reuse of historic buildings and obstruct the generation of sustainable values of these buildings.

\section{Research aim, objectives and methodology}

This paper aims to investigate the effectiveness of adaptive reuse as a novel approach for generating sustainable values 
of historic buildings in developing countries. Towards attaining this aim, a qualitative research approach is used to accomplish four objectives. First, literature review is used to investigate the concepts of sustainable development, sustainable values, adaptive reuse and characteristics of developing countries. Second, two case studies are presented and analysed to explain the role of adaptive reuse towards increasing the sustainable values of historic buildings. Third, a strategy with its action plan is developed to facilitate the adaptive reuse of historic buildings in developing countries. Finally, research conclusions are outlined and recommendations for professionals concerned with adaptive reuse of historic buildings are proposed.

\section{Results of literature review}

\subsection{Sustainable development}

Sustainable development has been defined in many ways. However, the most commonly quoted definition is derived from the Brundtland Report (World Commission on Environment and Development 1987), which defined it as development that meets the needs of the present generation without compromising the ability of future generations to meet their own needs. It contains two key concepts, namely, the needs and limitations. The first one represents, in particular, the essential needs of the world's poor in which prevailing priority should be given, whereas the latter refers to resources imposed by the state of technology and social organization and the environment's ability to meet present and future needs. Sustainable development aims to deliver products that enhance life's quality, achieve customer satisfaction, provide flexibility and adaptation to user changes, support desirable natural and social environments as well as maximize the efficient use of resources (Raynsford 2000). This will be achieved through enhancing efficiency and moderation in the use of materials, energy and development space. The 2030 agenda for sustainable development is shown in Figure 1.

\subsubsection{The relationship between sustainable development and built environment}

Sustainable development has three main pillars: environmental, social and economic. The interaction between these pillars creates three new pillars, namely, socialenvironmental, environmental-economic and economic-social (Figure 2; Rodriguez et al. 2002). Table 1 explains the focus of each pillar. Sustainable values are delivered through the optimum achievement of the required functions that meet the clients' and users' needs, desires and expectations in a way that protects the environment, enhances the society and prospers the economy. Within the built environment, sustainable development aims to deliver built assets that enhance quality of life, achieve customer satisfaction, offer flexibility and the potential to cater for user changes in the future, provide and support desirable natural and social environments and maximize the efficient use of resources (Othman 2007).

\subsection{Historic buildings}

A historic building or historic site is defined as an official location where pieces of political, military, cultural, or
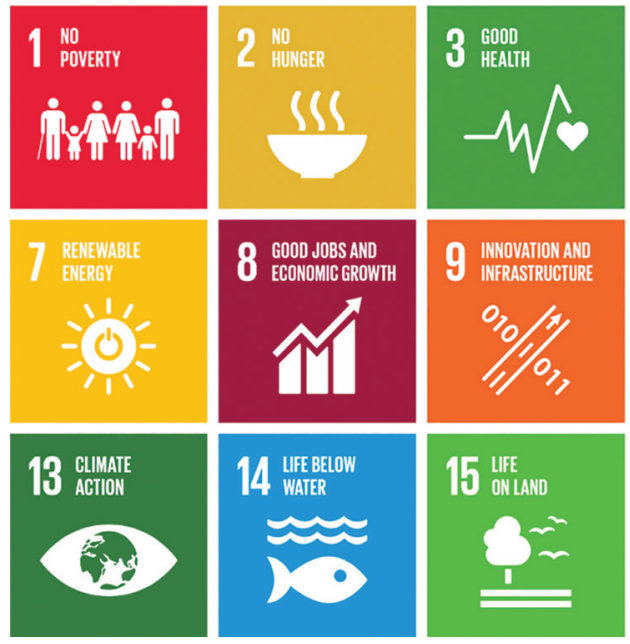
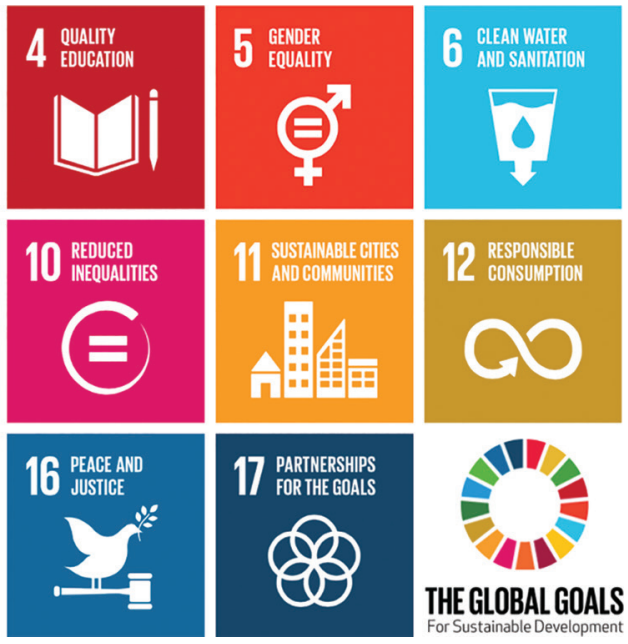

Fig. 1: The 2030 agenda for sustainable development (United Nations Development Programme 2018). 


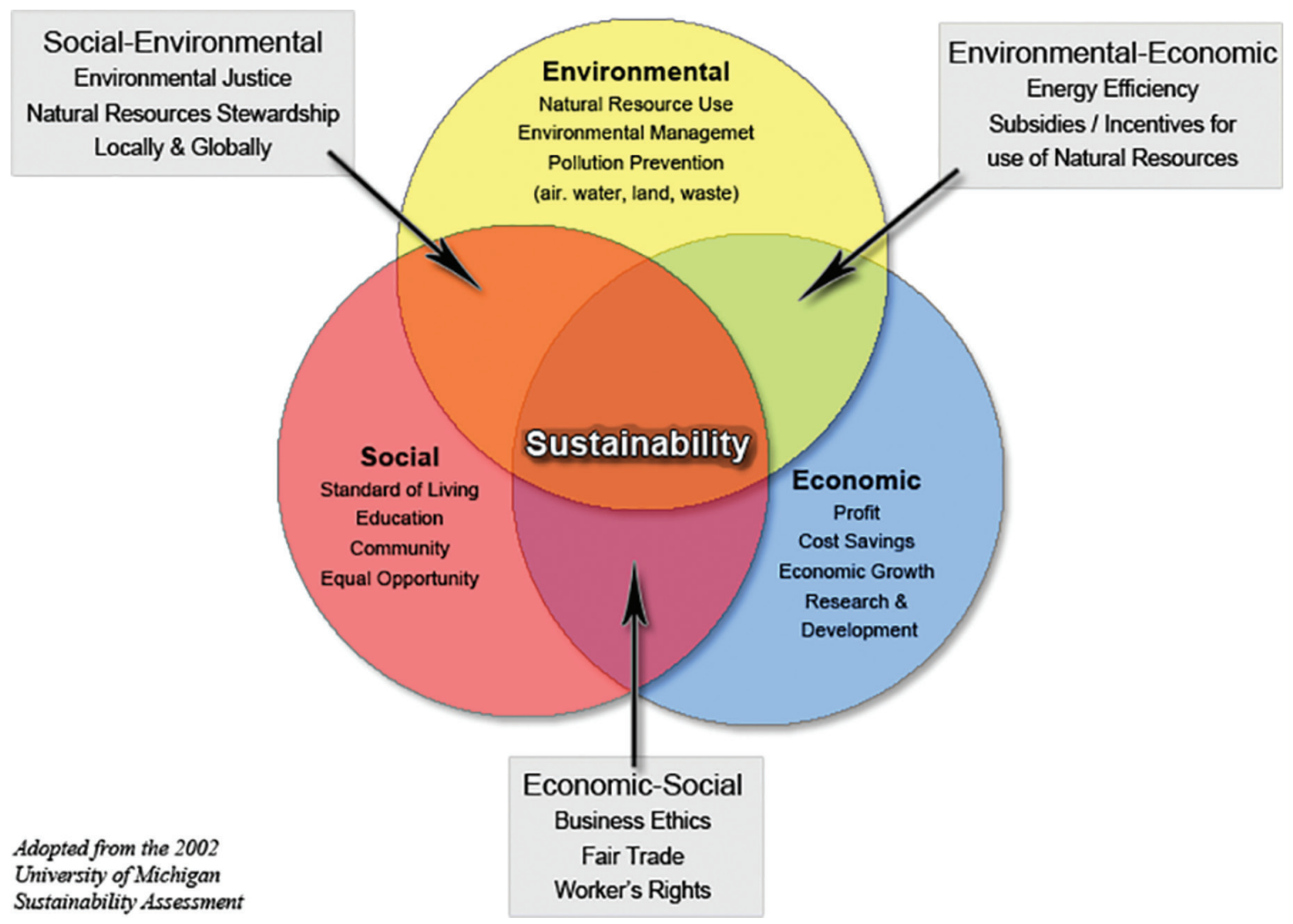

Fig. 2: Pillars of sustainable development (Rodriguez et al. 2002).

Tab. 1: The aim of sustainability pillars (developed by the authors).

\begin{tabular}{|c|c|}
\hline Sustainability pillar & Aim \\
\hline Environmental & $\begin{array}{l}\text { Focuses on using natural resources efficiently and reducing generated waste, pollution and emissions to the } \\
\text { environment. Moreover, it aims to reduce the adverse impact on human health, encourage the use of renewa- } \\
\text { ble raw materials and eliminate toxic substances }\end{array}$ \\
\hline Environmental-economic & $\begin{array}{l}\text { Focuses on achieving environmental objectives economically. This entails the reduction of unnecessary costs } \\
\text { and promotes efficient use of energy and natural resources. Moreover, it offers subsidies and incentives for } \\
\text { encouraging research centres and construction organizations to develop creative solutions to achieve econom- } \\
\text { ical sustainable environment (Othman et al. 2013) }\end{array}$ \\
\hline Economic & $\begin{array}{l}\text { Focuses on developing self-sustaining society that is able to use available resources efficiently to provide } \\
\text { individuals with their needs without reaching out for help from neighbouring societies or countries. This could } \\
\text { be achieved through offering job opportunities; enhancing education, R\&D and healthcare systems (Karlsson } \\
\text { 2009); promoting public and private partnerships; increasing productivity; escalating market share; adding } \\
\text { value; creating new markets; reducing cost through improving efficiency and reducing energy as well as con- } \\
\text { sumption of raw materials }\end{array}$ \\
\hline Economic-social & $\begin{array}{l}\text { Focuses on delivering sustainable economy without compromising societal needs through promoting business } \\
\text { ethics, ensuring fair trade and preserving workers' rights }\end{array}$ \\
\hline Social & $\begin{array}{l}\text { Focuses on promoting developing fair environment that accomplishes social justice in terms of resource } \\
\text { distribution within itself. It calls for a society that eradicates the discrimination of rights of its individuals } \\
\text { based on their ethnicity, sex, religion, age or social background (BenzuJK 2011). These rights that lead to a } \\
\text { standard quality of life include religious rights, right to housing, right to social security, right to work, freedom } \\
\text { of speech, right to travel and right to own property }\end{array}$ \\
\hline Social-environmental & $\begin{array}{l}\text { Focuses on the right of society members to have a fair share of the natural resources of the environment at } \\
\text { national and international levels. This ensures that environmental resources are not utilized by a portion of the } \\
\text { society, leaving the rest of the society with needs that cannot be met by the remaining resources }\end{array}$ \\
\hline
\end{tabular}


social history have been preserved due to their cultural heritage values. Law usually protects historic sites, and many have been recognized with the official national historic site status. A historic site may be any building, landscape, site or structure that is of local, regional or national significance. Owing to their merit, historic buildings could be graded as follows (Antiquities and Monuments Office, Leisure and Cultural Services Department 2017; Historicengland 2018):

- Grade 1 (buildings of outstanding merit): in this type of buildings, every effort should be made to preserve if possible.

- Grade 2 (buildings of special merit): in this type of buildings, efforts should be made to selectively preserve.

- Grade 3 (buildings of some merit): in this type of buildings, preservation in some form would be desirable and alternative means could be considered if preservation is not practicable.

Historic buildings represent an integral part of every country's heritage wealth. In spite of the territory on which they are located, historic buildings belong to all people worldwide. Owing to their structure and nature, many of these buildings are still standing in a stable state. However, they are suffering from being ignored and obsolete, which undermines the perception of their values (Bullen and Love 2010).

\subsubsection{Adaptive reuse of historic buildings}

Adaptive reuse is the process that changes a disused, obsolete or ineffective building into a new one that can be used for a different purpose (Burton 2014). It is mainly about reusing a building with its existing structure to extend its life cycle whilst performing a new function. Currently, this concept is practiced worldwide, in particular when the building has a unique architectural character and still in stable condition (Bullen 2007). Adaptive reuse is argued to be a challenging process. It is not only enough to preserve the building to perform a new function but also analysis of the existing fabric in contact with the heritage building is needed in order to make sure its originality is preserved. By doing this, the adaptive reuse process respects the historic value of the building, its existing context and avoids destroying its character (Misirlısoya and Günc 2016). In spite of the difficulties that encounter the adaptive reuse of historic building, extending their life cycle is a means of revitalizing these buildings and avoiding the demolition of old buildings that still have energy embedded in them as demolition is a waste of resources and the cost of reconstructing is very high (Burton 2014).

\subsubsection{Benefits of adaptive reuse of historic buildings}

Adaptive reuse helps communities, governments and developers reduce environmental, social and economic costs of continued urban development and expansion (Ball 1999; Wilkinson and Reed 2008; Bullen and Love 2009). It can transform heritage buildings into accessible and useable places as well as provide the added benefit of regenerating an area in a sustainable manner. Moreover, giving historic buildings new function is seen as an effective method towards a self-financing conservation (Yung and Chan 2012), which contributes to the economic pillar of sustainable development. Table 2 shows the relationship between the pillars of sustainable development and benefits of adaptive reuse.

\subsubsection{Factors affecting decision-making of adaptive reuse}

Based on the analysis of 60 semi-structured interviews conducted with stakeholders, including architects, developers

Tab. 2: The relationship between pillars of sustainability and the benefits of adaptive reuse (developed by authors).

\begin{tabular}{ll}
\hline $\begin{array}{l}\text { Pillars of } \\
\text { sustainable } \\
\text { development }\end{array}$ & Benefits of adaptive reuse \\
\hline $\begin{array}{l}\text { Environmental } \\
\text { Environmental- } \\
\text { economic }\end{array}$ & $\begin{array}{l}\text { Environmental enhancement } \\
\text { Less use of resources, energy and emissions } \\
\text { Enhancing the demand for preserved existing } \\
\text { buildings } \\
\text { Stimulating vacant neighbourhoods } \\
\text { Recovering energy embodied in buildings over a } \\
\text { large period of time } \\
\text { Economic development } \\
\text { Increasing the cost-effectiveness }\end{array}$ \\
Sconomic-social & $\begin{array}{l}\text { Expanding the life cycle of buildings } \\
\text { Giving value to resources of the community from } \\
\text { properties that are not productive } \\
\text { Cultural continuity, identity and sense of place } \\
\text { Giving a better aesthetic appearance to the built } \\
\text { environment } \\
\text { Heritage conservation and presentation } \\
\text { Decreasing consumption of land and } \\
\text { urban slump } \\
\text { Revitalization and upgrading of heritage districts } \\
\text { and architectural and technical innovation }\end{array}$ \\
\hline Social- \\
environmental
\end{tabular}


and building managers, to understand the views and experiences associated with adaptive reuse, Bullen and Love (2011) identified the following factors that affect the decision-making of adaptive reuse of historic buildings:

- cultural significance

- life cycle assessment

- heritage significance

- meeting sustainable development benchmarks

- economic sustainability

- environmental sustainability

- social sustainability

- value to local community

- orientation of building

- influence on local economy

- ability of building to adapt and

- views of stakeholders

In all, $68 \%$ and $83 \%$ of respondents stated that "cultural significance" and "heritage significance", respectively, should be assessed collaboratively with stakeholders during the phase of feasibility studies. In addition, the practical aspects of different use options have to be fully explored while keeping community values and heritage values in mind. Moreover, $74 \%$ of respondents mentioned that it is necessary to explicitly determine the technical and economic challenges of adaptive reuse. Furthermore, feasibility studies should identify whether expected outcomes can fulfil sustainability requirements and whether demolition and subsequent rebuilding would increase density and plot ratio. It is essential that feasibility studies explore how existing components and the intended construction methods would maintain the structural integrity of the building.

\subsection{Developing countries}

\subsubsection{Definition and characteristics}

About $85.4 \%$ of the world population lives in developing countries. Although they have the benefit of great mineral wealth, geographic locations, human resources, agricultural exports, and reasonably sophisticated manufacturing and services sectors, the majority of the people are poor and large parts of the rural areas are underdeveloped and lack in basic amenities such as clean water, healthcare, sanitation and electricity (Zeybek and Kaynak 2008; Cohen 2006). The World Development Report (World Bank Data Team 2016) classified countries into four income groups based on their gross national income (GNI) per capita. All low (GNI $\leq \mathrm{US} \$ 1,025)$, lower (GNI = US\$1,026-US\$4,035) and upper middle-income countries
$(\mathrm{GNI}=\mathrm{US} \$ 4,036-\mathrm{US} \$ 12,475)$ are classified as developing countries. In 2016, the United Nations developed the Human Development Index (HDI) as a measure to gauge the level of human development of countries. The index showed that $18 \%$ of the world's population lives in low human development countries (HDI $=<0.500$ ), while $52 \%$ populate countries falling in the medium human development category (HDI $=0.500-0.799$ ), all of which represent developing countries (Human Development Report 2016). Table 3 shows the relationship between characteristics of developing countries and sustainability pillars. Further analysis is performed by the authors to show the relationship between each characteristic and sustainability pillars.

\subsubsection{Challenges of adaptive reuse in developing countries}

There are a number of challenges that encounter the adaptive reuse of historic buildings in developing countries and their sustainability (Table 4).

\section{Results of case studies}

The case studies were selected to explore the role of adaptive reuse towards generating sustainable values of historic buildings and show the link between the issues raised in literature review and how they were reflected in the real world. The analysis of the findings, techniques and recommendations in these case studies was used to further establish a comprehensive understanding of the research topic.

\subsection{Case Study 1: Bayt al-Kritliya, Cairo, Egypt}

Bayt al-Kritliya is considered as one of the most magnificent residential Ottoman structures located in Darb al-Asfar, Cairo, Egypt, next to Ahmed Ibn Tulun Mosque. The structure was originally built in $1540 \mathrm{AD}$ and was followed by an expansion in 1632 AD. The house reflects the social patterns of Ottoman period with separated public and private areas, salamlik and haramlik, respectively. In addition, it contains other features such as mashrabiyas and maq'ad. Bayt al-Kritliya is considered as a world heritage that combines both tangible and intangible heritage features (Amer 2016). The structure consists of two houses linked with a 
Tab. 3: The relationship between characteristics of developing countries and sustainability pillars (developed by the authors).

\begin{tabular}{|c|c|c|c|c|c|c|c|}
\hline \multirow[t]{2}{*}{ Categories of characteristics } & \multirow[t]{2}{*}{ Characteristics } & \multicolumn{6}{|c|}{ Sustainable development pillars } \\
\hline & & 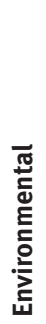 & 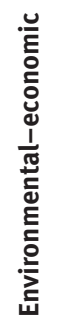 & 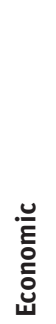 & 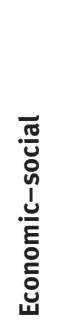 & $\frac{\pi}{\mathscr{0}}$ & 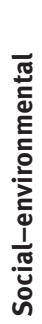 \\
\hline \multirow[t]{2}{*}{$\begin{array}{l}\text { Characteristics related to educa- } \\
\text { tion, training and brain drain }\end{array}$} & $\begin{array}{l}\text { Outflow of best brains (Connexions 2012; WDR 2012; } \\
\text { Kumar 2012; Economics 2010; Kintu 2008) }\end{array}$ & & & $\mathrm{x}$ & $\mathrm{x}$ & $\mathrm{x}$ & \\
\hline & Low standard of education and vocational training & & & $x$ & $\mathrm{x}$ & $x$ & $x$ \\
\hline \multirow{4}{*}{$\begin{array}{l}\text { Characteristics related to society, } \\
\text { demography and culture }\end{array}$} & Demographic characteristics & & & & & $\mathrm{x}$ & \\
\hline & $\begin{array}{l}\text { Sociocultural characteristics (Economic Concepts 2013; } \\
\text { Bobrova and Kalvina 2004) }\end{array}$ & & & & & $\mathrm{x}$ & \\
\hline & General and social backwardness & & & & & $\mathrm{x}$ & \\
\hline & $\begin{array}{l}\text { Sociocultural characteristics (Economic Concepts 2013; } \\
\text { Bobrova and Kalvina 2004) }\end{array}$ & & & & & $\mathrm{x}$ & \\
\hline \multirow{3}{*}{$\begin{array}{l}\text { Characteristics related to } \\
\text { healthcare, life expectancy and } \\
\text { growth rate of population }\end{array}$} & Poor health care & & & $\mathrm{x}$ & $\mathrm{x}$ & $\mathrm{x}$ & $\mathrm{x}$ \\
\hline & Low life expectancy & & & $\mathrm{x}$ & $\mathrm{x}$ & $\mathrm{x}$ & \\
\hline & $\begin{array}{l}\text { High rates of population growth and dependency burdens } \\
\text { (Economic Concepts 2013; WDR 2012; Connexions 2012; } \\
\text { Kumar 2012) }\end{array}$ & $\mathrm{x}$ & $\mathrm{x}$ & $\mathrm{x}$ & $\mathrm{x}$ & $x$ & $\mathrm{x}$ \\
\hline \multirow{11}{*}{$\begin{array}{l}\text { Characteristics related to } \\
\text { policy, economy, technology, } \\
\text { infrastructure and production }\end{array}$} & Corruption and political instability & $\mathrm{x}$ & $\mathrm{x}$ & $\mathrm{x}$ & $x$ & $\mathrm{x}$ & $x$ \\
\hline & Lack of capital and technology & & $\mathrm{x}$ & $\mathrm{x}$ & $\mathrm{x}$ & & \\
\hline & Dualistic economy & & & $x$ & $x$ & & \\
\hline & Vicious circle of poverty & $\mathrm{x}$ & $x$ & $\mathrm{x}$ & $\mathrm{x}$ & $x$ & $x$ \\
\hline & Low levels of productivity & & & $x$ & $\mathrm{x}$ & & \\
\hline & $\begin{array}{l}\text { Inequalities of national income distribution } \\
\text { Inadequate infrastructure }\end{array}$ & & & $x$ & $x$ & & \\
\hline & Heavy dependence on agricultural production & & & $x$ & $x$ & $\mathrm{x}$ & \\
\hline & Dependence on external resources & & & $x$ & $x$ & & \\
\hline & Lack of industries and enterprises & & & $x$ & $x$ & & \\
\hline & Underutilized natural resources & & $x$ & $x$ & $x$ & & \\
\hline & $\begin{array}{l}\text { High and rising levels of unemployment and underemploy- } \\
\text { ment (Economic Concepts 2013; Connexions 2012; Kumar } \\
\text { 2012; Economics 2010; Bobrova and Kalvina 2004; Fry 1998) }\end{array}$ & & & $x$ & $x$ & $x$ & \\
\hline
\end{tabular}

bridge, both referred to as Bayt al-Kritliya, which is named after its original Cretan female owner. Later on, the house was occupied by a British art collector named R.G. Gayer Anderson (Urban Regeneration Project for Historic Cairo 2014) (Figure 3).

\subsubsection{The adaptive reuse of Bayt al-Kritliya}

The house was commissioned for reuse into a museum in 1999 and followed by many phases. The museum was named "The Gayer-Anderson Museum" after his last owned name and is considered as a well-preserved example of the domestic architecture of Cairo during the seventeenth century. The house contains a variety of furniture, carpets and other collections. The project aimed at preserving the house and its diverse collections as well as its unique setting - having two houses linked together. Thus, the building was transformed into a museum. The project included the construction of a new conservation, creating new display spaces and landscaping the gardens to create an open-air area for cultural events and other facilities (Aga Khan Award for Architecture 2007).

\subsubsection{The project output}

The adaptive reuse of the building has changed the experience for the visitors as well as the staff of the house. Bayt al-Kritliya not only is considered an aesthetical preservation of the unique house architecture but also reflects a sustainable approach to the conservation 
Tab. 4: Challenges of adaptive reuse in developing countries and their relation to sustainability pillars (developed by the authors).

\begin{tabular}{|c|c|c|c|c|c|c|}
\hline Challenges & 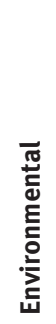 & 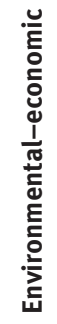 & 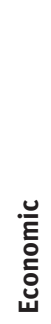 & 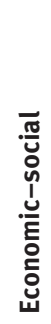 & $\begin{array}{l}\bar{\pi} \\
\dot{0} \\
\dot{u}\end{array}$ & 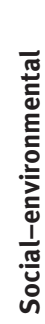 \\
\hline Uncertainty about economic viability & & & $x$ & & & \\
\hline Difficulty in achieving cost-efficiency & & & $\mathrm{x}$ & & & \\
\hline Hindrance of social inclusiveness & & & & & $x$ & \\
\hline Difficulty in establishing a sense of place and identity & & & & $x$ & $\mathrm{x}$ & \\
\hline Continuity of local community life & & & & & $\mathrm{x}$ & $\mathrm{x}$ \\
\hline Relatively less emphasis on environmentally sustainable building design & $x$ & & & & & $\mathrm{x}$ \\
\hline Overlooking the relationship between the historic building and the surrounding environment & & & & & $x$ & \\
\hline Ambiguities and difficulties in retaining historic setting & & & & & $\mathrm{x}$ & \\
\hline Supportive government policies and strategies & & & $x$ & $x$ & & \\
\hline
\end{tabular}

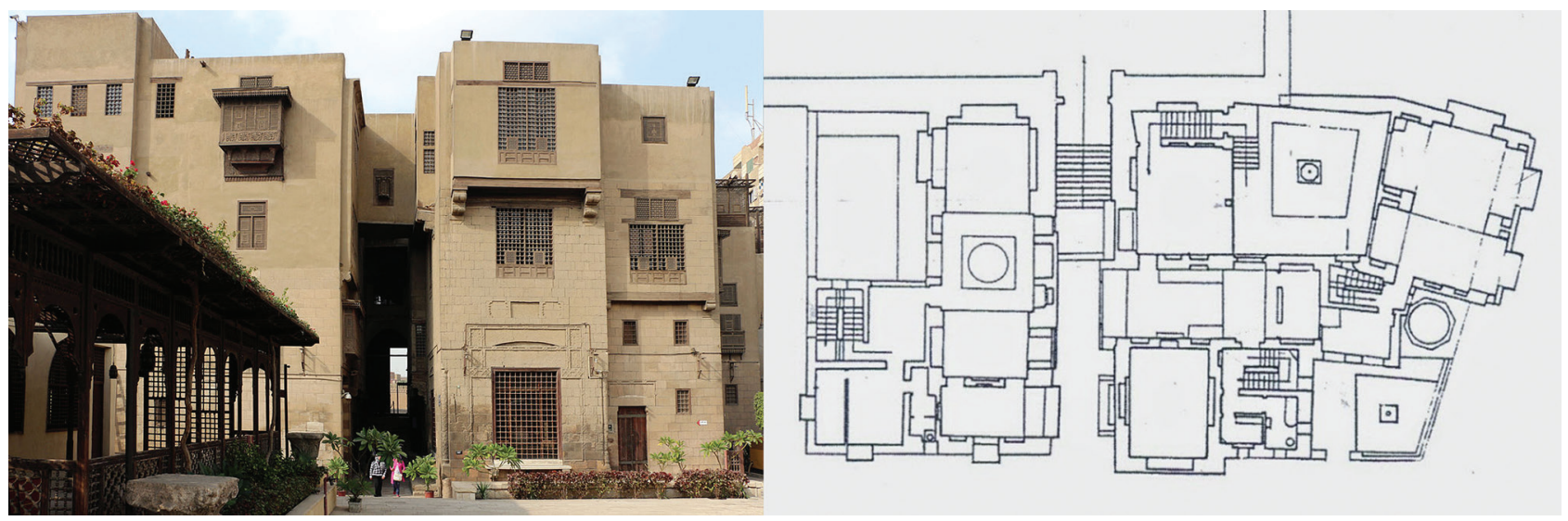

Fig. 3: Bayt al-Kritliya, Cairo, Egypt (Google images 2017).

of heritage structures and its treasured collections (Urban Regeneration Project for Historic Cairo 2014). Other activities took place inside the building that helped in raising awareness of neighbourhood children with regard to heritage importance (Aga Khan Award for Architecture 2007).

\subsection{Case Study 2: Kolkata Town Hall, Kolkata, India}

The British built Kolkata Town Hall in 1813 in Kolkata city in India. The building is located in the central business district, surrounded by many public administrative and commercial buildings. The Kolkata Town Hall was designed on the Palladian-Doric roman style, which reflects the physical and functional city during that time.
The building includes various ornaments in its floors. The building is regarded as an important heritage building that reflects history that took place inside it (Bose 2012) (Figures 4 and 5).

\subsubsection{The adaptive reuse of Kolkata Town Hall}

The process of adapting the building for reuse included many stages such as surveying existing condition, exploring the building materials, examining structural system conditions, estimating and tendering, assigning contractors, assigning restoration funds and managing the process. The process of restoring the building for public use included repair work to different building elements such as roofs, floors, doors and windows and building services. The building currently comprises the first high-tech 

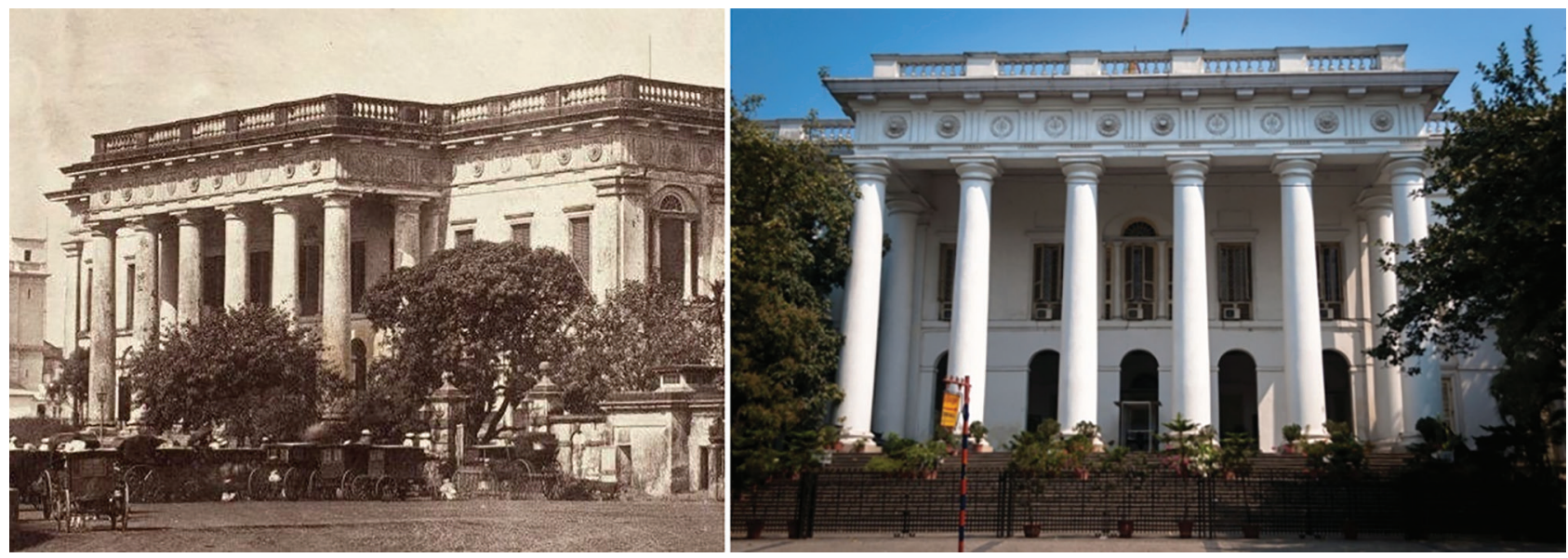

Fig. 4: Kolkata Town Hall before and after restoration (Google images 2017).
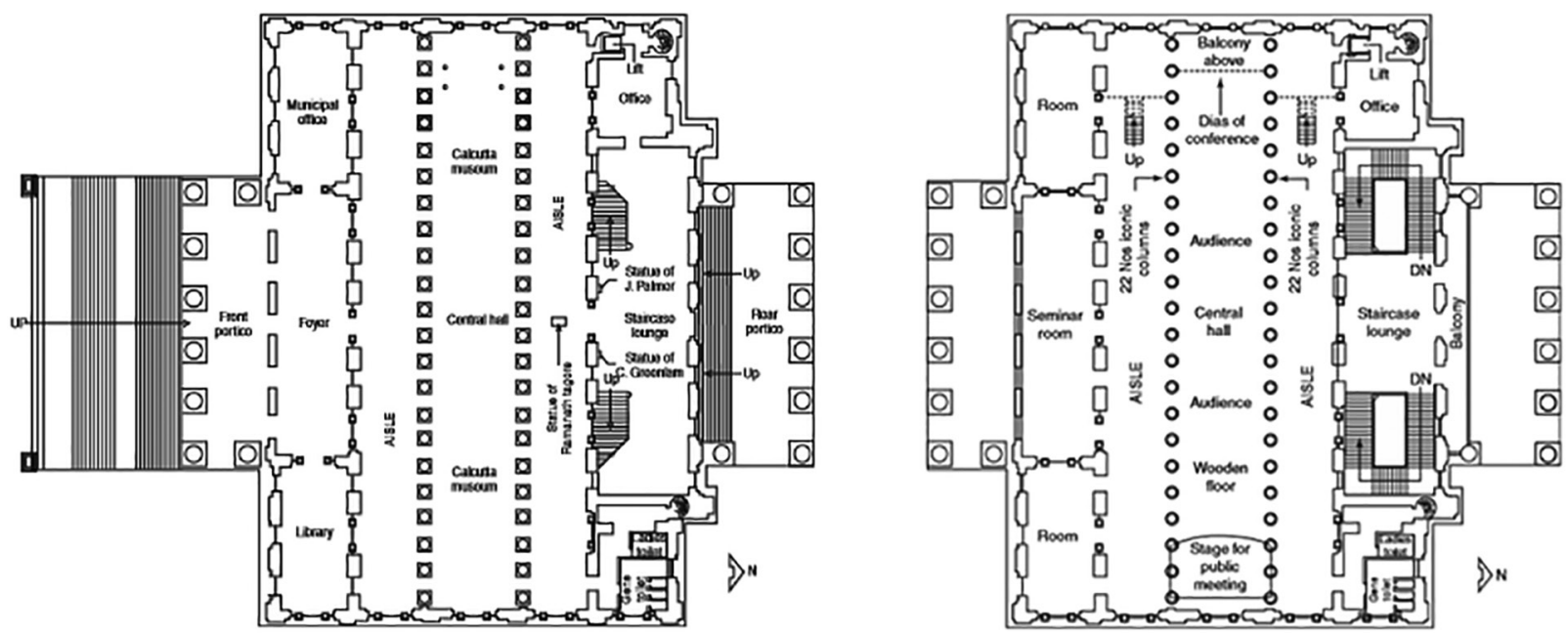

Fig. 5: Ground and first floors after restoration.

story-telling museum "Kolkata Panorama”, public gathering spaces, administrative area, academic seminar area and sociocultural event area (Bose 2012).

\subsubsection{The project output}

This project provided a new experience to the Indian government and highlighted the benefit of preserving heritage buildings through adaptive reuse. This approach was proven successful instead of demolishing heritage buildings, which was not used. Moreover, it helped in preserving the value held within these building walls. This conclusion was followed by supporting laws to help protect heritage buildings and facilitate the preservation process (Bose 2012). The adaptive reuse of Kolkata Town Hall emphasized a sustainable process to retain the value of it to its place and community.

\section{Discussion}

\subsection{Discussion of literature review}

The literature review mentioned earlier highlighted that achieving objectives of sustainable development plays a significant role towards enhancing quality of people's life. In addition, it calls for a balance between social, environmental and economic needs of the community and available resources. In spite the focus is usually directed at new buildings, this vision should include historic buildings. Adaptive reuse of historic buildings is needed to revitalize these buildings and maximize their sustainable values socially, economically and environmentally. Based on the analysis conducted by the authors, the adaptive reuse of historic buildings contributes to the different pillars of sustainability, providing a great opportunity for developing countries to sustainable values. Owing to the characteristics 
of developing countries, they suffer from lack of capabilities and skills, which affect the utilization of historic buildings.

\subsection{Discussion of case studies}

The case studies mentioned earlier highlighted the effectiveness of adaptive reuse process towards achieving sustainable values. Tables 5 and 6 provide an explanation of how adaptive reuse helped in achieving each sustainable value. Table 7 provides a summary of the two cases.

\subsection{Collective conclusion of case studies}

- Adaptive reuse is considered as a successful approach for conserving historic buildings by adjusting its use to match its location and time.

- Adaptive reuse is considered to be more economic in the analysed cases than demolishing the building and rebuilding it to satisfy a new use.
- Adaptive reuse buildings can include space adjustments, adding new structures to the original building to match the new function.

- Reusing heritage buildings as a cultural hub or museum helps in motivating tourism and community awareness of the heritage site.

\section{A strategy for facilitating adaptive reuse for generating sustainable values of historic buildings}

\subsection{Definition and objectives}

Strategy is high plan to achieve one or more goals or solution to a problem under conditions and uncertainty. It is the art and science of planning and marshalling resources for their most efficient and effective use (Freedman 2013). The Strategy for Adaptive Reuse of Historic Buildings

Tab. 5: Case Study 1: Bayt al-Kritliya's achievements of sustainability values (developed by the authors).

\begin{tabular}{|c|c|c|c|}
\hline & Sustainability values & Sustainable strategies & Sustainable actions \\
\hline \multirow{12}{*}{ 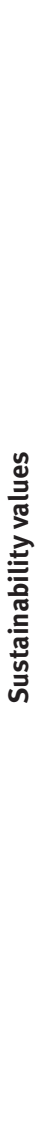 } & Environmental & $\begin{array}{l}\text { Less use of resources, } \\
\text { energy and emissions }\end{array}$ & $\begin{array}{l}\text { Since the house is preserved in its original setting, no need for mechanical } \\
\text { ventilation was required, thus reducing possible emissions } \\
\text { The use of low-maintenance lighting } \\
\text { The use of steel for construction to allow easy construction and reusability }\end{array}$ \\
\hline & $\begin{array}{l}\text { Environmental- } \\
\text { economic }\end{array}$ & $\begin{array}{l}\text { Stimulating vacant } \\
\text { neighbourhoods }\end{array}$ & $\begin{array}{l}\text { By providing new landscape around the building, the neighbourhood is } \\
\text { simulated by introducing new uses and public urban areas }\end{array}$ \\
\hline & \multirow[t]{2}{*}{ Economic } & Economic development & $\begin{array}{l}\text { The utilization of local craftsmanship from the local community provided } \\
\text { economic opportunities to the neighbourhood } \\
\text { The provision of object displays, descriptions and information panels } \\
\text { provides an improved experience for visitors, which in turn provides an } \\
\text { opportunity to simulate }\end{array}$ \\
\hline & & $\begin{array}{l}\text { Increasing the cost } \\
\text { effectiveness }\end{array}$ & $\begin{array}{l}\text { The use of low-maintenance solutions provides an opportunity for } \\
\text { reduction in running costs }\end{array}$ \\
\hline & \multirow[t]{4}{*}{ Economic-social } & $\begin{array}{l}\text { Giving value to resources } \\
\text { of the community from }\end{array}$ & $\begin{array}{l}\text { Through the use of the landscaped garden by local community as a public } \\
\text { open air space for cultural events }\end{array}$ \\
\hline & & $\begin{array}{l}\text { properties that are not } \\
\text { productive }\end{array}$ & $\begin{array}{l}\text { Through initiations made to provide training workshops for the staff and } \\
\text { locals to preserve the intangible heritage value }\end{array}$ \\
\hline & & & Through improving experience of visitors in the space \\
\hline & & & $\begin{array}{l}\text { Through initiatives to conduct documentation program of the building } \\
\text { collections }\end{array}$ \\
\hline & \multirow[t]{4}{*}{ Social } & $\begin{array}{l}\text { Cultural continuity, identity } \\
\text { and sense of place }\end{array}$ & $\begin{array}{l}\text { As the house was maintained in its original settings, the local community } \\
\text { can get a sense of how was it like to be in that period of time }\end{array}$ \\
\hline & & $\begin{array}{l}\text { Giving a better aesthetic } \\
\text { appearance to the built } \\
\text { environment }\end{array}$ & $\begin{array}{l}\text { The preservation of aesthetic values captured within the building allowed } \\
\text { craftsmen to reflect on the different Islamic and Arabesque forms }\end{array}$ \\
\hline & & $\begin{array}{l}\text { Heritage conservation and } \\
\text { presentation }\end{array}$ & $\begin{array}{l}\text { Preserved the great collection of objects, which dates back to different } \\
\text { periods; this includes Gayer-Anderson objects. }\end{array}$ \\
\hline & & & $\begin{array}{l}\text { Preservation of the intangible heritage such as social traditions and } \\
\text { customs was possible as the adaptive reuse of the building helped in } \\
\text { saving the original setting of the house and its collection }\end{array}$ \\
\hline
\end{tabular}


Tab. 6: Case Study 2: Kolkata Town Hall's achievements of sustainability values (developed by the authors).

\begin{tabular}{|c|c|c|c|}
\hline & Sustainability values & Sustainable strategies & Sustainable actions \\
\hline \multirow{9}{*}{ 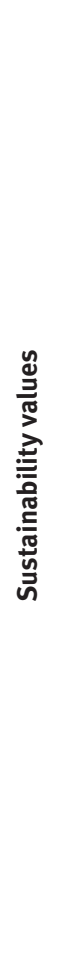 } & $\begin{array}{l}\text { Environmental- } \\
\text { economic }\end{array}$ & $\begin{array}{l}\text { Recovering energy } \\
\text { embodied in buildings } \\
\text { over a large period } \\
\text { of time }\end{array}$ & $\mathrm{N} / \mathrm{A}$ \\
\hline & Economic & Economic development & $\begin{array}{l}\text { Through the adaptive reuse of the building, the Indian government was } \\
\text { introduced to the benefit of preserving these buildings. This resulted in } \\
\text { introducing supporting laws to help the government protect and preserve } \\
\text { these buildings through this process (Bose 2012) }\end{array}$ \\
\hline & Economic-social & $\begin{array}{l}\text { Giving value to resources } \\
\text { of the community from } \\
\text { properties that are not } \\
\text { productive }\end{array}$ & $\begin{array}{l}\text { The provision of new public gathering spaces and administrative areas } \\
\text { provided a venue for sociocultural events }\end{array}$ \\
\hline & Social & Cultural continuity, identity & The functional and physical states of the city at that time are preserved. \\
\hline & & and sense of place & The preservation of ornaments provided an aesthetical sense of that era \\
\hline & & $\begin{array}{l}\text { Giving a better aesthetic } \\
\text { appearance to the built } \\
\text { environment }\end{array}$ & $\begin{array}{l}\text { Since repair works were incorporated in the adaptive reuse process, many } \\
\text { building elements were restored and repaired, which resulted in a better } \\
\text { aesthetical appearance }\end{array}$ \\
\hline & & $\begin{array}{l}\text { Heritage conservation and } \\
\text { presentation }\end{array}$ & $\begin{array}{l}\text { As the house was maintained in its original settings, the local community can } \\
\text { get a sense of how was it like to be in that period of time }\end{array}$ \\
\hline & & $\begin{array}{l}\text { Revitalization and } \\
\text { upgrading of heritage } \\
\text { districts and architectural } \\
\text { and technical innovation }\end{array}$ & $\begin{array}{l}\text { The adaptive reuse included high technology and innovation. The building } \\
\text { represents the first high-tech story-telling museum in India }\end{array}$ \\
\hline & $\begin{array}{l}\text { Social- } \\
\text { environmental }\end{array}$ & $\begin{array}{l}\text { Decreasing consumption of } \\
\text { land and urban slump }\end{array}$ & $\begin{array}{l}\text { Through the establishment of supporting laws, more heritage buildings could } \\
\text { be adapted and reused, which reduces the demand on vacant land }\end{array}$ \\
\hline
\end{tabular}

Tab. 7: Summary of benefits of adaptive reuse explored in each case study (developed by the authors).

\begin{tabular}{|c|c|c|c|}
\hline $\begin{array}{l}\text { Pillars of sustainable devel- } \\
\text { opment }\end{array}$ & Benefits of adaptive reuse & 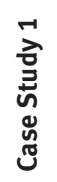 & 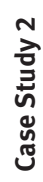 \\
\hline Environmental & Environmental enhancement & & $\mathrm{x}$ \\
\hline \multirow[t]{4}{*}{ Environmental-economic } & Less use of resources, energy and emissions & $\mathrm{x}$ & \\
\hline & Enhancing the demand for preserved existing buildings & $\mathrm{x}$ & $\mathrm{x}$ \\
\hline & Stimulating vacant neighbourhoods & $\mathrm{x}$ & \\
\hline & Recovering energy embodied in buildings over a large period of time & $x$ & $\mathrm{x}$ \\
\hline \multirow[t]{2}{*}{ Economic } & Economic development & $\mathrm{x}$ & $\mathrm{x}$ \\
\hline & Increasing the cost-effectiveness & $x$ & \\
\hline \multirow[t]{2}{*}{ Economic-social } & Expanding the life cycle of buildings & $x$ & $\mathrm{x}$ \\
\hline & Giving value to resources of the community from properties that are not productive & $\mathrm{x}$ & $\mathrm{x}$ \\
\hline \multirow[t]{3}{*}{ Social } & Cultural continuity, identity and sense of place & $\mathrm{x}$ & $\mathrm{x}$ \\
\hline & Giving a better aesthetic appearance to the built environment & $\mathrm{x}$ & $\mathrm{x}$ \\
\hline & Heritage conservation and presentation & $\mathrm{x}$ & $\mathrm{x}$ \\
\hline \multirow[t]{2}{*}{ Social-environmental } & Decreasing consumption of land and urban slump & & $\mathrm{x}$ \\
\hline & Revitalization and upgrading of heritage districts and architectural and technical innovation & & $x$ \\
\hline
\end{tabular}

(SARHB) (hereinafter referred to as "the strategy" or the "SARHB") is a proposed strategy developed by this research to facilitate adopting adaptive reuse as a tool for generating sustainable values of historic buildings. It describes the various domains that governmental authorities responsible for heritage and antiquities in developing countries can adopt to revitalize and generate sustainable values of historic buildings. 


\subsection{The need for the strategy}

Literature review and analysis of the case studies showed the importance of historic buildings and the need to develop a strategy to facilitate the use of adaptive reuse as a novel approach for generating sustainable values of historic buildings in developing countries. In addition, the necessity for the SARHB stems from the importance of supporting governmental initiatives in developing countries towards maintaining their heritage and utilizing their values.

\subsection{Description of the strategy}

Figure 6 describes the six domains of the developed strategy. It includes:

- government level

- society level

- economy level

- environment level

- law level and

- technology level

Each level of the strategy domains is explained in Table 8.

\subsection{Action plan for implementation of strategy}

The aim of this action plan is to facilitate the implementation of the abovementioned strategy. It consists of the following steps.

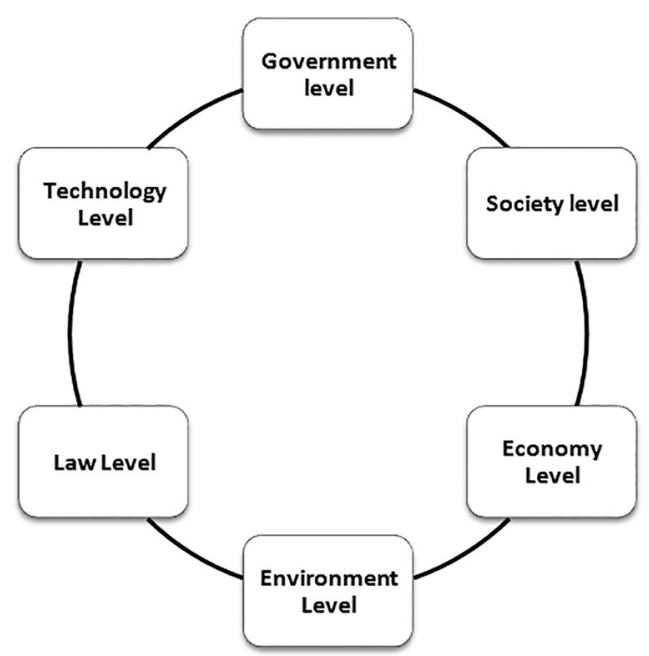

Fig. 6: Strategy for adaptive reuse of historic buildings (developed by authors).
- diagnosing current challenge of adaptive reuse of historic buildings in developing countries;

- identifying and evaluating improvement opportunities and strategies;

- planning and implementing improvement opportunities;

- monitoring and evaluating obtained results and

- implementing corrective actions and closing out.

Table 9 describes the action plan including its objectives, activities, tools and techniques, involved personnel and needed resources as well as the output of every step.

\section{Conclusions and recommendations}

Having reviewed the concepts of sustainable development, sustainable values, characteristics of developing countries and adaptive reuse and through keeping in mind the learned lessons of case studies, the research may reach the following conclusions and recommendations:

- Governments worldwide are concerned with delivering facilities and infrastructure projects that achieve the social, economic and environmental objectives of sustainable development. This calls for a balance between the infinite needs of the society and the limited available resources.

- Despite the fact that attention is directed towards new projects, this vision should encompass historic buildings. Adaptive reuse of historic buildings in developing countries is a novel approach for revitalizing these buildings and maximizing their sustainable values.

- Contrary, developing countries encounter many challenges that affect the utilization and adaptive reuse of historic buildings.

Hence, the research comes to the following recommendations.

- Adaptive reuse of historic buildings should be used as an essential approach to revitalize these buildings and generate sustainable social, economic and environmental values in developing countries.

- Challenges of developing countries toward adaptive reuse should be overcome.

- The strategy, developed by this research and its action plan, provided a platform and a start point for facilitating the adaptive reuse of historic buildings in society, economy, environment, law and technology domains. 
Tab. 8: Explanation of the strategy domains (developed by authors).

\begin{tabular}{|c|c|}
\hline Strategy domain & Domain focus \\
\hline Government & $\begin{array}{l}\text { The government domain of the strategy is concerned with the role of the government in preserving and maintain- } \\
\text { ing historic buildings, being national and international valuable elements, as well as the responsibility towards } \\
\text { sustainable development of communities that live around these buildings. This includes issuing laws and policies for } \\
\text { preservation, initiating projects for adaptive reuse, inviting national and international experts and organisations to } \\
\text { conduct the adaptive reuse work and securing needed approvals and financial resources and human skills. }\end{array}$ \\
\hline Society & $\begin{array}{l}\text { The society domain of the strategy focuses on engaging society members in the decision-making process, identifying } \\
\text { stakeholders and their positive and negative impacts on the project. In addition, the society level helps defining the } \\
\text { suitable adaptive reuse type that meets the skills of the surrounding community and the level of their participation }\end{array}$ \\
\hline Economy & $\begin{array}{l}\text { The economy domain of the strategy concentrates on completing the adaptive reuse process in an economic } \\
\text { way that adds value to the historic building. It focuses also on creating job opportunities to the surrounding } \\
\text { communities and helps improving their income and increasing the country’s GDP. In addition, the economy } \\
\text { domain encourages the use of the restored and adapted reuse building to generate fund to maintain the } \\
\text { historic building and cover its operating costs }\end{array}$ \\
\hline Environment & $\begin{array}{l}\text { The environment domain of the strategy focuses on conducting the adaptive reuse of the historic building without } \\
\text { affecting the building or the surrounding environment in a negative way. This entails conducting Environmental } \\
\text { Impact Assessment to the intended reuse of the building and selecting proper materials that match with those of the } \\
\text { original building and its structure. Another dimension of the environment domain is to consider the impact of the } \\
\text { surrounding environment on the performance and sustainability of the historic building }\end{array}$ \\
\hline Law & $\begin{array}{l}\text { The law domain of the strategy is concerned with establishing the regulations and enforcing the rules that organize } \\
\text { the preservation, restoration and adaptive reuse of historic buildings. To maintain the stability of these buildings } \\
\text { and ensure the delivered sustainable values, approvals of governmental authorities responsible for these buildings } \\
\text { should be secured before the commencement of any work. Moreover, stated penalties and punishments should be } \\
\text { applied to every community member who violates the rules and damages the adapted historic building }\end{array}$ \\
\hline Technology & $\begin{array}{l}\text { The technology domain of the strategy is mainly concerned with the use of state-of-the-art tools and techniques } \\
\text { in the adaptive reuse of historic buildings. This will help ensuring the timely completion of the work at the desired } \\
\text { quality level. Furthermore, presentation technology (e.g., sound, light and laser) could be applied to entertain the } \\
\text { visitors and allow the use of the historic building at different times of the day throughout the year }\end{array}$ \\
\hline
\end{tabular}

Tab. 9: Detailed description of the developed action plan.

\begin{tabular}{ll}
\hline Action plan phase & Description of phase components \\
\hline Step 1 & Diagnosing current challenge of adaptive reuse of historic buildings in developing countries \\
\hline Objective & To investigate the current challenges that obstruct the adaptive reuse of historic buildings in developing countries \\
Activities & Studying the current status of historic buildings (e.g. damaged, unstable, in good state) \\
& Identifying the environmental, social and economic impacts of historic buildings on the surrounding environment \\
& Identifying, validating and classifying the challenges of adaptive reuse of historic buildings in developing countries \\
& Conducting an orientation meeting prior to the study to establish strategic issues (study location, team, budget, \\
& resources, etc.) \\
& Gaining governmental approvals and support of decision makers and top management to facilitate securing the \\
& needed resources as well as accepting and implementing the study decisions \\
Tools and techniques & Literature review \\
& Survey questionnaires \\
Interviews & Case studies \\
Involved person- & Support of government, decision makers and senior management \\
nel and needed & Governmental authorities \\
resources & Heritage specialists \\
& Project managers \\
& Design and construction teams \\
& Different project stakeholders
\end{tabular}


Tab. 9: Detailed description of the developed action plan (Continued).

\begin{tabular}{|c|c|}
\hline Action plan phase & Description of phase components \\
\hline Output & $\begin{array}{l}\text { Training programmes } \\
\text { Legal specialists } \\
\text { IT specialists } \\
\text { Identified, validated and classified current challenges of adaptive reuse of historic buildings } \\
\text { in developing countries }\end{array}$ \\
\hline Step 2 & Identifying and evaluating improvement opportunities and strategies \\
\hline Objective & $\begin{array}{l}\text { To identify improvement opportunities and strategies towards overcoming the challenges of adaptive reuse of his- } \\
\text { toric buildings in developing countries }\end{array}$ \\
\hline Activities & $\begin{array}{l}\text { Identifying improvement opportunities with regard to the different domains of strategy, namely, government, society, } \\
\text { economy, environment, law and technology. This may include education and training, development of human } \\
\text { resources, policy and management and sustainability } \\
\text { Generating innovative ideas to achieve the identified improvement opportunities } \\
\text { Evaluating the generated improvement ideas }\end{array}$ \\
\hline Tools and techniques & $\begin{array}{l}\text { Brainstorming and team consensus } \\
\text { Developing technical, economic, social and time-feasibility studies } \\
\text { Cost and benefit analysis of improvement opportunities }\end{array}$ \\
\hline $\begin{array}{l}\text { Involved person- } \\
\text { nel and needed } \\
\text { resources }\end{array}$ & $\begin{array}{l}\text { Governmental authorities } \\
\text { Heritage specialists } \\
\text { Project managers } \\
\text { Design and construction teams } \\
\text { Different project stakeholders } \\
\text { Training programmes } \\
\text { Legal specialists } \\
\text { IT specialists }\end{array}$ \\
\hline Output & Identified and evaluated improvement opportunities, strategies and action plans \\
\hline
\end{tabular}

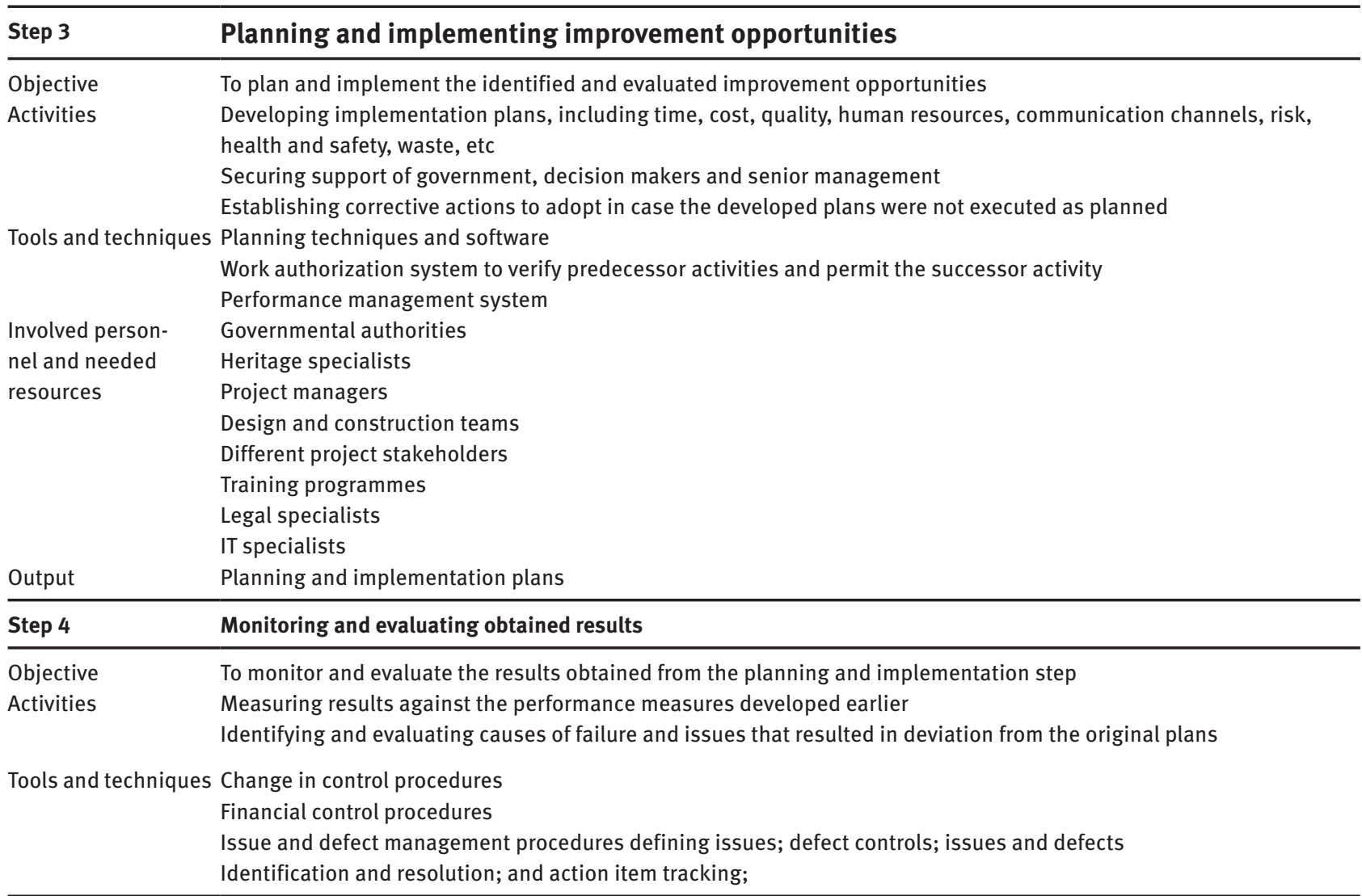


Tab. 9: Detailed description of the developed action plan (Continued).

\begin{tabular}{|c|c|}
\hline Action plan phase & Description of phase components \\
\hline $\begin{array}{l}\text { Involved person- } \\
\text { nel and needed } \\
\text { resources }\end{array}$ & $\begin{array}{l}\text { Governmental authorities } \\
\text { Heritage specialists } \\
\text { Project managers } \\
\text { Design and construction teams } \\
\text { Different project stakeholders } \\
\text { Training programmes } \\
\text { Legal specialists } \\
\text { IT specialists }\end{array}$ \\
\hline Output & Action plans and corrective actions to overcome the issues raised during the adaptive reuse of historic buildings \\
\hline Step 5 & Implementing corrective actions and closing out \\
\hline $\begin{array}{l}\text { Objective } \\
\text { Activities }\end{array}$ & $\begin{array}{l}\text { To implement the corrective actions developed during the previous step and close-out projects } \\
\text { Implementing corrective actions } \\
\text { Documenting learned lessons and sharing them with governmental authorities, decision makers, design and } \\
\text { construction teams and related project stakeholders } \\
\text { Obtaining acceptance by the client to formally close the project or phase } \\
\text { Conducting post-occupancy evaluation } \\
\text { Closing out all procurement activities and ensuring termination of all relevant agreements } \\
\text { Performing team members' assessment and releasing project resources }\end{array}$ \\
\hline Tools and techniques & $\begin{array}{l}\text { Expert judgement } \\
\text { Reporting } \\
\text { Procurement management }\end{array}$ \\
\hline $\begin{array}{l}\text { Involved person- } \\
\text { nel and needed } \\
\text { resources }\end{array}$ & $\begin{array}{l}\text { Governmental authorities } \\
\text { Client organisation } \\
\text { Project managers } \\
\text { Design and construction teams } \\
\text { Different project stakeholders } \\
\text { Training programmes }\end{array}$ \\
\hline Output & Successfully delivered adapted reuse of historic buildings \\
\hline
\end{tabular}

\section{References}

Aga Khan Award for Architecture. (2007). Restoration of Bayt al-Kritliyya Presentation Panels. Courtesy of Architect. Aga Khan Award for Architecture, Geneva.

Amer, M. B. (2016, September 5). Heritage Economic: A case study on Bayt al-Kritliya (Gayer-Anderson Museum). Available at https://works.bepress.com/mohamed-amer/5/ on 10 February 2017.

Antiquities and Monuments Office, Leisure and Cultural Services Department. (2017, June 14). Assessment of 1,444 Historic Buildings. Available at http://www.amo.gov.hk/en/ built2.php.

Ball, R. (1999). Developers, regeneration and sustainability issues in the reuse of vacant buildings. Building Research and Information, 27(3), pp.140-148.

BenzuJK (2011). Three aspects of Sustainable Environmental Architecture. [Online]. Available from: http://www. architecture-student.com/sustainabledesign/threeaspects-of-sustainableenvironmental-architecture/ (accessed 5 April 2018).

Bobrova, V., \& Kalvina, J. (2004). Economic: Educational the Allowance. GOU OGU, Orenburg, p. 208.
Bose, S. (2012). Restoration of Town Hall in Kolkata for adaptive reuse: A case study. Structural Survey, 30(3), pp. 280-291.

Bullen, P. A. (2007). Adaptive reuse and sustainability of commercial buildings. Facilities, 25(1/2), pp. 20-31.

Bullen, P. A., \& Love, P. E. D. (2009). Residential regeneration and adaptive reuse: Learning from the experiences of Los Angeles. Structural Survey, 27(5), pp. 351-360.

Bullen, P. A., \& Love, P. E. D. (2010). The rhetoric of adaptive reuse or reality of demolition: Views from the field. Cities, 27(4), pp. 215-224.

Bullen, P. A., \& Love, P. E. D. (2011). Factors influencing the adaptive reuse of buildings. Journal of Engineering, Design and Technology, 9(1), pp. 32-46.

Burton, B. (2014). "Adaptive Reuse of commercial buildings" Building Science Forum, Available at http://www.monstercommercial.com/adaptive-re-use-of-commercialbuildings/.

Cohen, B. (2006). Urbanization in developing countries: Current trends, future projections, and key challenges for sustainability. Technology in Society, 28, pp. 63-80.

Connexions. (2012). Characteristics of Developing countries. Available at http://cnx.org/content/m22818/latest on 26 June 2016.

Department of Environment and Heritage (DEH). (2004), Adaptive Reuse. Commonwealth of Australia, Canberra. 
Economics. (2010). Characteristics of Developing Countries. 17(2). Available at http://economydetail.blogspot.com/2010_02_01_ archive.html.

Economic Concepts. (2013). Common Characteristics of Developing/Third World Countries. Available at http://www. economicsconcepts.com/common_characteristics_of_ developing_countries.htm on 21 April 2013.

Freedman, L. (2013). Strategy. Oxford University Press. ISBN 978-0-19-932515-3.

Fry, M. J. (1998). Saving, Investment, Growth, and Financial Distortions in the Pacific Basin and Other Developing Areas. International Economic Journal, 12(Spring), pp. 1-24.

Historicengland. (2018). Listed Buildings. Retrieved from Historic England: Available at https://historicengland.org.uk/listing/ what-is-designation/listed-buildings/

Human Development Report. (2016). [Online]. Available at http:// hdr.undp.org/en/media/HDR_2016_EN_Table1.pdf on 12 February 2018.

Karlsson, I. (2009). Social and Economic Aspects of Sustainable Development. Uppsala University, The Baltic University Programme, Uppsala Centre for Sustainable Development, Sweden.

Kintu, A.B. (2008). Characteristics of Developing Countries. Available at http://www.shvoong.com/social-sciences/1758902-characteristics-developing-countries/ on 22 April 2013.

Kumar, A. (2012). Major Characteristics of Developing Countries.

Matisoff, D. C., Noonany, D. S., \& Flowers, M. E. (2016). Green Buildings: Economics and Policies. Review of Environmental Economics and Policy.

Mısırlısoya, D., \& Günc, K. (2016). Adaptive reuse strategies for heritage buildings: A holistic approach. Sustainable Cities and Society, 26, pp. 91-98.

Othman, A. A. E. (2007). Generating Sustainable Values and Achieving Client Satisfaction in Construction Projects through Maintenance Management: The Case of Housing Projects in Abu Dhabi, United Arab Emirates. Architectural Engineering and Design Management, 3(3), pp. 145-159.

Othman, A. A. E., Ghaly, M., \& ZainulAbidin, N. (2013). Lean Principles: An Innovative Approach for Achieving Sustainability in the Egyptian Construction Industry. Organisation, Technology and Management in Construction: An International Journal, 6(1), pp. 917-932.
Raynsford, N. (2000) Sustainable construction: The government's role. Proceedings of the Institution of Civil Engineers: Civil Engineering, 138(special issue 2), pp. 16-22.

Rodriguez, S., Roman, M., Sturhahn, S., \& Terry, E. (2002). Sustainability assessment and reporting for the University of Michigan's Ann Arbor Campus. Master's thesis, University of Michigan, Ann Arbor, 1-396.

United Nations Development Programme. (2018). Sustainable Development Goals (SDGs). Available at UNDP.org: http:// www.eg.undp.org/content/egypt/en/home/sdgoverview/ post-2015-development-agenda.html

Urban Regeneration Project for Historic Cairo. (2014). Study on the Monuments in the Action Area. UNESCO, World Heritage Centre, Cairo.

WDR. (2012). World Development Report. Available at https:// openknowledge.worldbank.org/handle/10986/4391.

Wilkinson, S., \& Reed, R. (2008). The business case for incorporating sustainability in office buildings: The adaptive reuse of existing buildings. In: Proceedings of 14th Annual Pacific Rim Real Estate Society Conference, Pacific Rim Real Estate Society, Kuala Lumpur.

Wilkinson, S., Reed, R., \& Kimberley, J. (2009). Using building adaptive reuse to deliver sustainability in Australia. Structural Survey, 27(1), pp. 46-61.

World Bank Data Team. (2016). New country classifications by income level. Available at worldbank.org: https://blogs.worldbank.org/opendata/new-countryclassifications-2016.

World Commission on Environment and Development. (1987). Our Common Future. Oxford University Press, Oxford.

Yung, E. H., \& Chan, E. H. (2012). Implementation challenges to the adaptive reuse of heritage buildings: Towards the goals of sustainable, low carbon cities. Habitat International, 36(3), pp. 352-361.

Zeybek, H. and Kaynak, M. (2008). Role of Mega Projects in Sustainable Urban Transport in Developing Countries: The Case of Istanbul Marmaray Project. In: Proceedings of Codatu XIII: Sustainable Development Challenges of Transport in Cities of the Developing World: Doing What Works, 12-14 November 2008, Ho Chi Minh City, Vietnam. Available at http://www.codatu.org/english/conferences/ codatu13/CodatuXIII-CDrom/codCD-Zeybek.pdf on 27 February 2018. 